\title{
Plasma and pituitary hormone changes and follicular development after unilateral ovariectomy in cyclic rats*
}

\author{
T. Otani† and S. Sasamoto \\ Laboratory of Veterinary Physiology, Tokyo University of Agriculture and Technology, Fuchu, \\ Tokyo 183, Japan
}

\begin{abstract}
Summary. After unilateral ovariectomy of 4-day-cyclic rats, plasma FSH increased over control values for $6-12 \mathrm{~h}$ after the surgery regardless of whether unilateral ovariectomy was performed before or after $08: 00 \mathrm{~h}$ on the day of dioestrus, after which time compensatory ovulation did not occur at the next oestrus. Pituitary content of FSH also increased from $6 \mathrm{~h}$ after unilateral ovariectomy. In contrast, plasma and pituitary levels of $\mathrm{LH}$ and prolactin were generally within the range of values of sham-operated rats.

Treatment with pentobarbitone between $13: 00$ and $14: 00 \mathrm{~h}$ on the day of pro-oestrus in rats unilaterally ovariectomized after $08: 00 \mathrm{~h}$ on dioestrus delayed the next spontaneous ovulation by 1 day and was accompanied by a rise in plasma FSH concentrations for $24 \mathrm{~h}$ and a doubling in the number of ovulations from the remaining ovary. Follicle counts showed an increase in large healthy follicles $(\geq 501$ $\mu \mathrm{m}$ diam.) and a decrease in atretic follicles in pentobarbitone-treated rats. It is suggested that the FSH rise induces compensatory follicular development and decreases follicular atresia when there is sufficient time for follicles to develop before the LH surge.
\end{abstract}

\section{Introduction}

When unilateral ovariectomy is performed during the oestrous cycle, the remaining ovary usually ovulates the same number of oocytes as do both ovaries of intact animals. In 4-day cyclic rats, compensatory ovulation at the next oestrus occurs only after unilateral ovariectomy before early dioestrus but not when the operation is at late dioestrus or thereafter (Toyoda, 1962; Peppler \& Greenwald, 1970a). Unilateral ovariectomy before early dioestrus also results in a transient increase in serum levels of FSH whereas LH levels change only slightly (Howland \& Skinner, 1973; Ramirez \& Sawyer, 1974; Welschen \& Dullaart, 1974). The increase in serum FSH may be responsible for compensatory ovulation through increased proliferation of developing follicles (Peppler \& Greenwald, 1970b) or by decreased follicular atresia (Welschen, Dullaart \& de Jong, 1978).

The purpose of the present investigation was to determine the changes in concentrations of gonadotrophins in plasma and pituitary after unilateral ovariectomy performed before or after the critical time to establish the interrelationship between secretory changes of FSH and follicular development in the remaining ovary.

*Reprint requests to $\mathrm{S}$. Sasamoto.

† Present address: Research Institute, Daiichi Seiyaku Co. Ltd, Edogawa-ku, Tokyo, Japan. 


\section{Materials and Methods}

Virgin female rats of the Wistar strain, 70-90 days old and weighing 210-300 g, were used. They were maintained under a lighting schedule of $14 \mathrm{~h}$ light:10 h darkness (lights on at 05:00 h). Only rats which had 3 or more consecutive 4-day cycles, as judged by daily vaginal smears, were used.

Unilateral ovariectomy or sham-operation was performed via a small, dorsolateral flank incision under ether anaesthesia.

Immediately after removal from the cage, each rat was killed by decapitation and trunk blood was collected in a heparinized beaker. Individual plasma samples were obtained after centrifugation and stored at $-20^{\circ} \mathrm{C}$ until assayed. At autopsy the pituitary gland was removed within $5 \mathrm{~min}$ and homogenized in $5.0 \mathrm{ml}$ cold saline $(9 \mathrm{~g} \mathrm{NaCl} / 1)$. After centrifugation of the homogenate, the resulting supernatant fraction was stored at $-20^{\circ} \mathrm{C}$ until assayed. Oviducts were examined for oocytes by the method of Burdick \& Whitney (1941).

Some of the unilaterally ovariectomized animals were treated i.p. with pentobarbitone sodium (40 mg/kg body weight) between 13:00 and 14:00 h on the next pro-oestrous day after the operation to check the effect of postponement of ovulation for $24 \mathrm{~h}$ on the ovulation response.

Ovaries were fixed in Bouin's fluid, sectioned serially at $10 \mu \mathrm{m}$ and stained with haematoxylin and eosin. All sections from one ovary of each animal were examined. Each section was scanned and the diameter of the follicle calculated by measuring the two diameters at right angles to each other from basement membrane to basement membrane in the largest section of the follicle displaying the oocyte.

Follicles greater than $201 \mu \mathrm{m}$ in diameter were counted and rated as normal or atretic according to the criteria described by Hirshfield \& Midgley (1978) and Harman, Louvet \& Ross (1975). Follicles were considered to be undergoing atresia whenever the granulosa cells lost homogeneity or cellular debris appeared in the antrum or whenever the oocyte showed obvious signs of degeneration, such as fragmentation or loss of the nuclear membrane. Healthy and atretic follicles were classified according to size into three arbitrary groups: $201-300 \mu \mathrm{m}$, 301-500 $\mu \mathrm{m}$ and $\geq 501 \mu \mathrm{m}$.

Plasma and pituitary levels of FSH, LH and prolactin were measured using the radioimmunoassays described previously (Sasamoto, Harada \& Taya, 1979; Taya \& Sasamoto, 1980). All results were expressed in terms of NIAMDD-rat-FSH-RP1, -rat-LH-RP1 and -rat-prolactin-RP1. The intra- and inter-assay coefficients of variation were respectively $4 \cdot 1$ and $8.8 \%$ for $\mathrm{FSH}, 2.2$ and $14.5 \%$ for $\mathrm{LH}$ and 2.1 and $10.7 \%$ for prolactin. The lower limits of sensitivity were $10 \mathrm{ng} \mathrm{FSH} /$ tube $(50 \mathrm{ng} / \mathrm{ml}$ plasma $), 8 \mathrm{ng} \mathrm{LH} /$ tube $(40 \mathrm{ng} / \mathrm{ml}$ plasma) and $0.6 \mathrm{ng}$ prolactin/tube ( $3 \mathrm{ng} / \mathrm{ml}$ plasma).

For statistical analysis of results the $t$ test was used. A difference of $P<0.05$ was considered statistically significant.

\section{Results}

\section{Ovulation number after unilateral ovariectomy at various stages of the oestrous cycle}

The normal number (mean \pm s.e.m.) of spontaneous ovulations per pair of ovaries in 10 intact rats was $13 \cdot 3 \pm 0 \cdot 7$. When unilateral ovariectomy was performed at $08: 00 \mathrm{~h}$ on the day of dioestrus, the remaining ovary produced $12.6 \pm 0.9(n=5)$ oocytes. However, unilateral ovariectomy at $17: 00$ or $20: 00 \mathrm{~h}$ on the day of dioestrus was never followed by compensatory ovulation $(17: 00 \mathrm{~h}, 8.8 \pm 0.7, n=6 ; 20: 00 \mathrm{~h}, 9.6 \pm 0.2, n=5)$. These results indicate that in the 4-day cyclic rat the critical time after which unilateral ovariectomy no longer results in compensatory ovulation at the next oestrus occurred between 08:00 and 17:00 $\mathrm{h}$ on the day of dioestrus. 


\section{Concentrations of plasma FSH, LH and prolactin}

When unilateral ovariectomy was performed at $11: 00 \mathrm{~h}$ on the day of metoestrus (leading to compensatory ovulation at the next oestrus), FSH levels increased significantly within $6 \mathrm{~h}$, showed a plateau at $12 \mathrm{~h}$ and then decreased to control levels by $24 \mathrm{~h}$ after surgery (Text-fig. 1a).
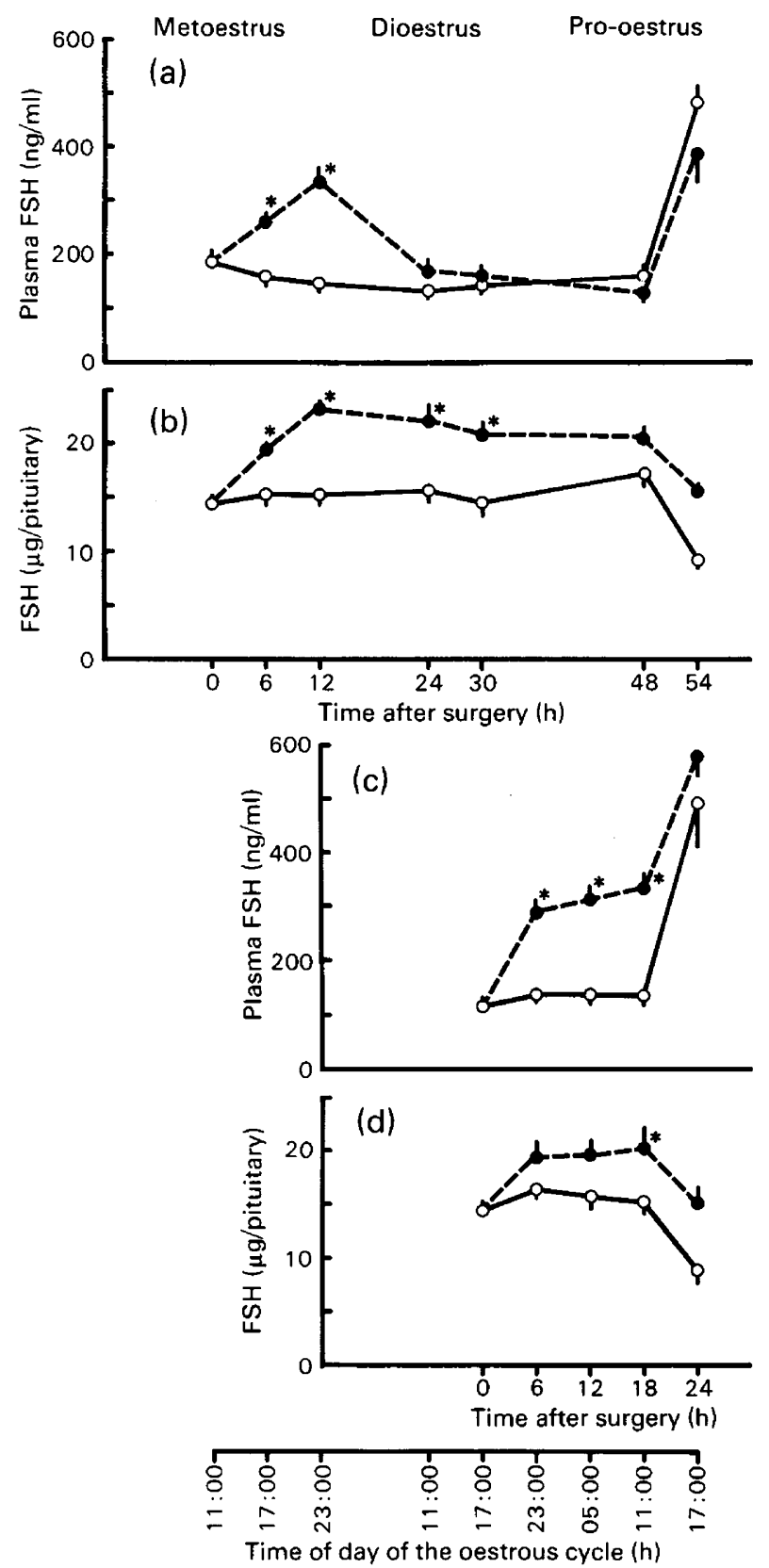

Text-fig. 1. Plasma concentrations and pituitary content of FSH after unilateral ovariectomy $(\mathcal{O})$ or sham-operation $(O)$ at $11: 00 \mathrm{~h}$ on the day of metoestrus $(\mathrm{a}, \mathrm{b})$ or at 17:00 h on the day of dioestrus (c, d). Values are mean \pm s.e.m. for 5 rats. ${ }^{*} P<0.05$ compared with the values in sham-operated controls ( $t$ test). 
When unilateral ovariectomy was performed at $17: 00 \mathrm{~h}$ on the day of dioestrus (no compensatory ovulation), plasma FSH also increased significantly $6 \mathrm{~h}$ after the surgery and these levels were maintained until $18 \mathrm{~h}$ when there was a preovulatory surge of FSH (Text-fig. 1c).

Concentrations of plasma $\mathrm{LH}$ and prolactin were similar after unilateral ovariectomy to those in sham-operated animals.

\section{Pituitary FSH, LH and prolactin content}

When unilateral ovariectomy was performed at $11: 00 \mathrm{~h}$ on the day of metoestrus, pituitary content of FSH increased significantly $6 \mathrm{~h}$ later and this increase persisted until 11:00 h on the day of pro-oestrus (Text-fig. 1b). After unilateral ovariectomy late on the day of dioestrus, pituitary FSH began to increase by $6 \mathrm{~h}$ although a significant increase was noted only after $18 \mathrm{~h}$ (Text-fig. 1d).

Pituitary values of $\mathrm{LH}$ and prolactin after unilateral ovariectomy did not differ significantly from those of the corresponding control animals.

\section{Effect of pentobarbitone sodium}

As shown in Table 1, treatment with pentobarbitone had no effect on ovulation number at the delayed oestrus in unilaterally ovariectomized metoestrous rats, but increased the number of ovulations in rats unilaterally ovariectomized at $17: 00 \mathrm{~h}$ on the day of oestrus.

Table 1. A $24-\mathrm{h}$ delay of the next spontaneous ovulation by pentobarbitone treatment $(40 \mathrm{mg} / \mathrm{kg}$ body wt at 13:00-14:00 $\mathrm{h}$ on day of pro-oestrus) after unilateral ovariectomy and the consequent number of ovulations

\begin{tabular}{cclcc}
\hline $\begin{array}{c}\text { Time of unilateral } \\
\text { ovariectomy }\end{array}$ & $\begin{array}{c}\text { Pentobarbitone } \\
\text { treatment }\end{array}$ & Day of autopsy & $\begin{array}{c}\text { No. of rats ovulating/ } \\
\text { no. examined }\end{array}$ & $\begin{array}{c}\text { Mean } \pm \text { s.e.m. no. of } \\
\text { oocytes/rat }\end{array}$ \\
\hline 11:00 h on day of & - & Next oestrus & $5 / 5$ & $13 \cdot 3 \pm 0.6$ \\
metoestrus & + & Delayed oestrus & $5 / 5$ & $13 \cdot 8 \pm 1 \cdot 3$ \\
17:00 h on day of & - & Next oestrus & $6 / 6$ & $8 \cdot 8 \pm 0 \cdot 7$ \\
dioestrus & + & Delayed oestrus & $7 / 7$ & $13 \cdot 0 \pm 0.6^{*}$ \\
\hline
\end{tabular}

${ }^{*} P<0.05$ compared with the value in the rats without pentobarbitone treatment ( $t$ test).

As expected, injection of pentobarbitone between 13:00 and 14:00 h on the day of pro-oestrus completely inhibited the $\mathrm{LH}$ surge which normally occurs late on the afternoon of pro-oestrus (Text-fig. 2). However, the transient increase of plasma FSH that occurs after unilateral ovariectomy at 17:00 h on the day of dioestrus was still obtained (Text-fig. 2).

In all rats the surges of plasma $\mathrm{LH}$ and FSH characteristic of a $24 \mathrm{~h}$ delay in ovulation occurred in the afternoon of the delayed day of pro-oestrus.

\section{Follicular development}

The results for various groups of rats are given in Table 2. In sham-operated animals treated with pentobarbitone, the number of follicles with a diameter $\geq 501 \mu \mathrm{m}$ was similar in all 6 groups: in each ovary there were approximately half the total number of large follicles to be ovulated the next oestrus. In the unilaterally ovariectomized rats, the numbers of follicles had increased to 


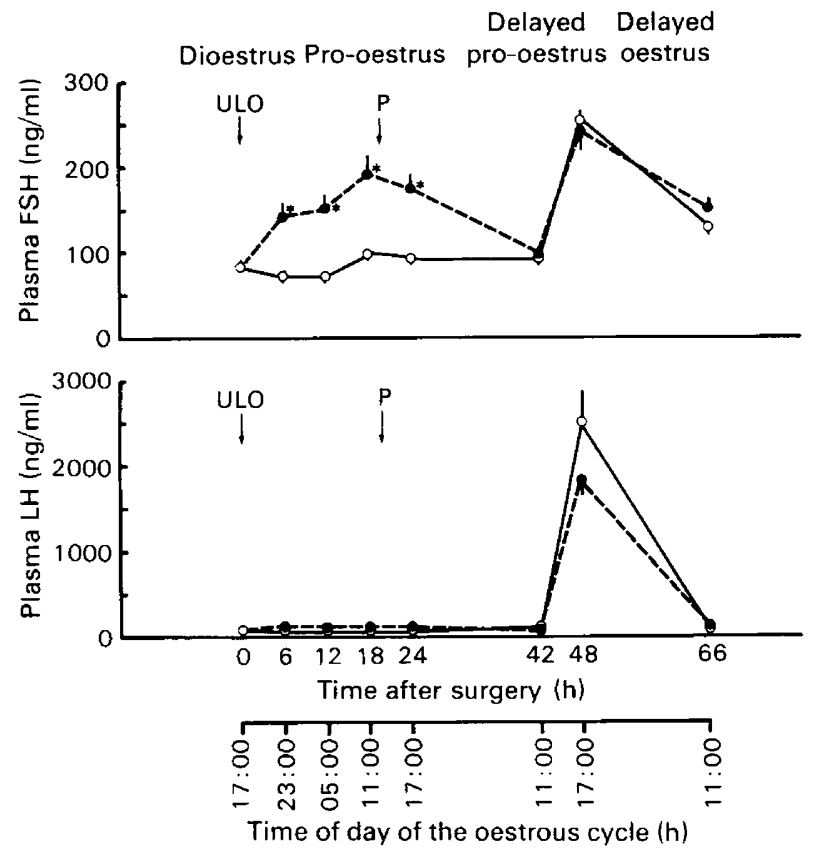

Text-fig. 2. Plasma concentrations of FSH and LH after unilateral ovariectomy ( $(\bullet)$ or sham-operation $(\mathrm{O})$ at $17: 00 \mathrm{~h}$ on the day of dioestrus, followed by pentobarbitone treatment $(\mathrm{P})$ ( $40 \mathrm{mg} / \mathrm{kg}$ body weight) given i.p. between 13:00 and 14:00 h on the next pro-oestrous day after operation. Values are mean \pm s.e.m. for 5-12 rats. ${ }^{*} P<0.05$ compared with the values in sham-operated rats $(t$ test).

double that of controls by 17:00 h on the day of delayed pro-oestrus. Compared with the controls there was an increase in the number of healthy follicles measuring $301-500 \mu \mathrm{m}$ by $18 \mathrm{~h}$ after unilateral ovariectomy, and a corresponding decrease in the numbers of atretic follicles.

\section{Discussion}

The present results indicate that, in 4-day cyclic rats, the critical time after which unilateral ovariectomy no longer results in compensatory ovulation at the next oestrus occurred between 08:00 and 17:00 h on the day of dioestrus, confirming the observations of Toyoda (1962) and Peppler \& Greenwald (1970a). Unilateral ovariectomy performed before or after the critical time was invariably followed by a transient increase of plasma FSH 6-12 h or more after surgery, although LH and prolactin levels were not altered, as found by Howland \& Skinner (1973), Ramirez \& Sawyer (1974) and Welschen \& Dullaart (1974). In hamsters there is no increase in serum FSH concentrations after unilateral ovariectomy (Bast \& Greenwald, 1977).

The transient increase of plasma FSH in rats occurred with increased pituitary content of FSH at the same time and was probably due to a decrease in the amount of inhibin-like substance(s) (Welschen et al., 1978). The increased FSH presumably initiates follicular growth as well as preventing Graafian follicles from becoming atretic. By increasing the number of healthy Graafian follicles, inhibin-like substance(s) from the remaining ovary may increase again and terminate the FSH surge.

Histological examination of follicular development in rats treated with pentobarbitone after unilateral ovariectomy at 17:00 $\mathrm{h}$ on the day of dioestrus indicated that an increase in the 
Table 2. Mean \pm s.e.m. numbers of follicles larger than $201 \mu \mathrm{m}$ per ovary in pentobarbitone-treated rats ( $40 \mathrm{mg} / \mathrm{kg}$ body wt at $13: 00-14: 00 \mathrm{~h}$ on day of pro-oestrus) after unilateral ovariectomy (ULO) or shamoperation performed at 17:00 h on the day of dioestrus

\begin{tabular}{|c|c|c|c|c|c|c|c|c|c|c|}
\hline \multirow[b]{3}{*}{ Treatment } & \multirow{3}{*}{$\begin{array}{c}\text { No. } \\
\text { of } \\
\text { animals }\end{array}$} & \multirow{3}{*}{$\begin{array}{l}\text { Stage of } \\
\text { oestrous } \\
\text { cycle }\end{array}$} & \multirow{3}{*}{$\begin{array}{c}\text { Time } \\
\text { killed } \\
\text { after } \\
\text { operation } \\
\text { (h) }\end{array}$} & \multicolumn{7}{|c|}{ Number of follicles } \\
\hline & & & & \multicolumn{2}{|c|}{$201-300 \mu \mathrm{m}$} & \multicolumn{2}{|c|}{$301-500 \mu \mathrm{m}$} & \multicolumn{2}{|c|}{$\geq 501 \mu \mathrm{m}$} & \multirow[b]{2}{*}{ Total } \\
\hline & & & & Healthy & Atretic & Healthy & Atretic & Healthy & Atretic $\dagger$ & \\
\hline \multirow[b]{2}{*}{ Sham } & & Dioestrus & & & & & & & & \\
\hline & 5 & $17: 00 \mathrm{~h}$ & 0 & $\begin{array}{r}15.4 \\
\pm 4.5\end{array}$ & $\begin{array}{r}24.6 \\
\pm 7.2\end{array}$ & $\begin{array}{r}15.4 \\
+3.3\end{array}$ & $\begin{array}{r}12.2 \\
\pm 1.7\end{array}$ & $\begin{array}{r}4.8 \\
\pm 1.4\end{array}$ & 0 & $\begin{array}{r}72.4 \\
+\quad 15.1\end{array}$ \\
\hline Sham & 5 & $23: 00 \mathrm{~h}$ & 6 & $\begin{array}{r}12.8 \\
+1.7\end{array}$ & $\begin{array}{r}22.6 \\
+4.6\end{array}$ & $\begin{array}{r}7.0 \\
+1.3\end{array}$ & $\begin{array}{r}14.2 \\
+1.8\end{array}$ & $\begin{array}{r}5.6 \\
\pm 0.4\end{array}$ & $0.6(3)$ & $\begin{array}{r}62.8 \\
\pm 6.5\end{array}$ \\
\hline \multirow[t]{2}{*}{ ULO } & 4 & $23: 00 \mathrm{~h}$ & 6 & $\begin{array}{r}12.3 \\
\pm 1.4\end{array}$ & $\begin{array}{r}23.0 \\
+4.3\end{array}$ & $\begin{array}{r}8.5 \\
+1.0\end{array}$ & $\begin{array}{r}14.1 \\
\pm 1.5\end{array}$ & $\begin{array}{r}5.5 \\
+0.5\end{array}$ & $0.3(1)$ & $\begin{array}{r}63.5 \\
+2.9\end{array}$ \\
\hline & & Pro-oestrus & & & & & & & & \\
\hline Sham & 5 & $11: 00 \mathrm{~h}$ & 18 & $\begin{array}{r}35.4 \\
\pm 2.0\end{array}$ & $\begin{array}{r}36.6 \\
\pm 4.0\end{array}$ & $\begin{array}{r}23.8 \\
\pm 2.8\end{array}$ & $\begin{array}{r}27.8 \\
\pm 2.0\end{array}$ & $\begin{array}{r}6.0 \\
\pm 0.7\end{array}$ & $0.4(2)$ & $\begin{array}{l}130.0 \\
\pm 7.1\end{array}$ \\
\hline ULO & 5 & $11: 00 \mathrm{~h}$ & 18 & $\begin{array}{r}30.0 \\
\pm 2.4\end{array}$ & $\begin{array}{r}26.0 \\
\pm 8.6\end{array}$ & $\begin{array}{c}36.0 \\
\pm 2.8^{* *}\end{array}$ & $\begin{array}{c}18 \cdot 0 \\
\pm 2 \cdot 1^{* * *}\end{array}$ & $\begin{array}{r}4.0 \\
\pm 0.8\end{array}$ & $\begin{array}{r}3.4 \\
\pm 0.7\end{array}$ & $\begin{array}{r}117.4 \\
\pm 13.6\end{array}$ \\
\hline Sham & 5 & $17: 00 \mathrm{~h}$ & 24 & $\begin{array}{r}35.8 \\
\pm 2.9\end{array}$ & $\begin{array}{r}40.6 \\
+4.7\end{array}$ & $\begin{array}{r}17.4 \\
\pm 1.7\end{array}$ & $\begin{array}{r}13.6 \\
\pm 2.3\end{array}$ & $\begin{array}{r}7.0 \\
+1.0\end{array}$ & $0.6(2)$ & $\begin{array}{r}115.0 \\
\pm 5.9\end{array}$ \\
\hline \multirow[t]{2}{*}{ ULO } & 5 & $17: 00 \mathrm{~h}$ & 24 & $\begin{array}{c}21.4 \\
\pm 2 \cdot 1^{* *}\end{array}$ & $\begin{array}{r}35.4 \\
+2.9\end{array}$ & $\begin{array}{r}31.0 \\
\pm 3.8^{*}\end{array}$ & $\begin{array}{r}8.6 \\
+1.2\end{array}$ & $\begin{array}{r}6.4 \\
+1.1\end{array}$ & $0.2(1)$ & $\begin{array}{r}103.0 \\
\pm 6.4\end{array}$ \\
\hline & & $\begin{array}{l}\text { Delayed } \\
\text { pro- } \\
\text { oestrus }\end{array}$ & & & & & & & & \\
\hline Sham & 3 & $11: 00 \mathrm{~h}$ & 42 & $\begin{array}{r}31.3 \\
\pm 8.2\end{array}$ & $\begin{array}{r}29.0 \\
\pm 5.7\end{array}$ & $\begin{array}{r}14.3 \\
\pm 1.9\end{array}$ & $\begin{array}{r}31.3 \\
\pm 3.8\end{array}$ & $\begin{array}{r}6.3 \\
\pm 0.3\end{array}$ & $1 \cdot 0(3)$ & $\begin{array}{r}113.3 \\
+14.7\end{array}$ \\
\hline ULO & 5 & $11: 00 \mathrm{~h}$ & 42 & $\begin{array}{r}23.2 \\
\pm 2.2\end{array}$ & $\begin{array}{r}28.4 \\
\pm 4.8\end{array}$ & $\begin{array}{c}34.6 \\
\pm 1.7^{* *}\end{array}$ & $\begin{array}{l}7.6 \\
\pm 1.7 * *\end{array}$ & $\begin{array}{r}8.0 \\
\pm 0.8\end{array}$ & $1 \cdot 0(1)$ & $\begin{array}{r}102.8 \\
+3.5\end{array}$ \\
\hline Sham & 5 & $17: 00 \mathrm{~h}$ & 48 & $\begin{array}{r}29.2 \\
\pm 2.0\end{array}$ & $\begin{array}{r}22.8 \\
\pm 2.7\end{array}$ & $\begin{array}{r}9.8 \\
\pm 1.0\end{array}$ & $\begin{array}{r}14.2 \\
\pm 2.0\end{array}$ & $\begin{array}{r}6.6 \\
+0.7\end{array}$ & $0.2(1)$ & $\begin{array}{r}82.8 \\
+5.7\end{array}$ \\
\hline ULO & 5 & $17: 00 \mathrm{~h}$ & 48 & $\begin{array}{r}25.0 \\
+3.7\end{array}$ & $\begin{array}{c}38.8 \\
\pm 4.0^{*}\end{array}$ & $\begin{array}{c}28 \cdot 8 \\
4 \cdot 0^{* *}\end{array}$ & $\begin{array}{l}10.2 \\
\pm 0.5\end{array}$ & $\begin{array}{c}13.8 \\
\pm 1.5^{* * *}\end{array}$ & $0.4(2)$ & $\begin{array}{l}117.0 \\
\pm 8.0\end{array}$ \\
\hline
\end{tabular}

* $P<0.05 ;{ }^{* *} P<0.01$ compared with the values of sham-operated controls ( $t$ test).

+ Numbers in parentheses indicate numbers of animals having follicles in this size range.

number of medium-sized antral follicles in the remaining ovary occurred from $18 \mathrm{~h}$ after unilateral ovariectomy and was paralleled by a decrease in number of atretic follicles in this size range and of healthy small antral follicles (201-300 $\mu \mathrm{m}$ in diameter). Hirshfield \& Midgley (1978) and Richards (1979) reported that follicular atresia was most marked in medium-sized follicles (201-400 $\mu \mathrm{m}$ in diameter) and suggested that there may be a critical stage during follicular development when, unless rescued, most follicles became atretic. Early atresia can be prevented by increased gonadotrophin levels in prepubertal mice (Peters, 1976). When unilateral ovariectomy was performed on the day of oestrus, compensatory ovulation results from increased proliferation of small follicles in the course of the cycle rather than from decreased follicular atresia (Peppler \& Greenwald, 1970b). Unilateral ovariectomy at dioestrus in 5-day cyclic rats resulted in an increase in the number of healthy Graafian follicles $28 \mathrm{~h}$ after surgery by preventing the follicles from undergoing atresia (Welschen et al., 1978).

The present values for the size distribution of antral follicles on the day of oestrus in 4-day cyclic rats are lower than those for 5-day cyclic rats (Hirshfield \& Midgley, 1978). These smaller antral follicles on the day of dioestrus of 4-day cyclic rats may require a longer period $(48 \mathrm{~h})$ to develop into large Graafian follicles in response to the FSH surge after unilateral ovariectomy.

Therefore, the transient rise in plasma FSH after unilateral ovariectomy may be responsible for compensatory follicular development that would result in the ovulation of twice as many oocytes from the remaining ovary when there is a sufficient period for follicles to develop into a state capable of ovulating in response to the LH surge. 
We thank Dr. G. S. Greenwald for reading the original manuscript and for valuable suggestions; and the Rat Pituitary Hormone Distribution Program, NIAMDD, NIH, and Dr A. F. Parlow, U.S.A., for radioimmunoassay materials. This work was supported in part by a grant-in-aid for Co-operative Research from the Ministry of Education of Japan (No. 336029 in 1978 and 1979).

\section{References}

Bast, J.D. \& Greenwald, G.S. (1977) Acute and chronic elevation in serum levels of FSH after unilateral ovariectomy in the cyclic hamster. Endocrinology $100,955-966$.

Burdick, H.O. \& Whitney, R. (1941) Ovulation induced in mice by single injection of follutein or untreated human pregnancy urine. Am. J. Physiol. 132, 405-410.

Harman, S.M., Louvet, J.P. \& Ross, G.T. (1975) Interaction of estrogen and gonadotropins on follicular atresia. Endocrinology, 96, 1145-1152.

Hirshfield, A.N. \& Midgley, A.R., Jr (1978) Morphometric analysis of follicular development in the rat. Biol. Reprod. 19, 597-605.

Howland, B.E. \& Skinner, K.R. (1973) Effect of hemiovariectomy on serum FSH and LH levels during the oestrous cycle in the rat. J. Reprod. Fert. 32, 501-503.

Peppler, R.D. \& Greenwald, G.S. (1970a) Effects of unilateral ovariectomy on ovulation and cycle length in 4- and 5-day cycling rats. Am. J. Anat. 127, 1-8.

Peppler, R.D. \& Greenwald, G.S. (1970b) Influence of unilateral ovariectomy on follicular development in cycling rats. Am. J. Anat. 127, 9-14.

Peters, H. (1976) The development and maturation of the ovary. Annals Biol. anim. Biochim. Biophys. 16, 271-278.

Ramirez, V.D. \& Sawyer, C.H. (1974) A sex difference in the rat pituitary FSH response to unilateral gonad- ectomy as revealed in plasma radioimmunoassays. Endocrinology 94, 475-482.

Richards, J.S. (1979) Hormonal control of ovarian follicular development: A 1978 perspective. Recent Prog. Horm. Res. 35, 343-368.

Sasamoto, S., Harada, S. \& Taya, K. (1979) Prolonged release by dioestrous rats of follicle-stimulating hormone during the period of ovulation induced by luteinizing hormone releasing hormone. J. Endocr. 81, 109-118.

Taya, K. \& Sasamoto, S. (1980) Initiation of follicular maturation and ovulation after removal of the litter from the lactating rat. J. Endocr. 87, 393-400.

Toyoda, Y. (1962) Studies on the mechanism determining ovulation rate in the rat. II. On the number of ova shed after unilateral ovariectomy. Jap. J. Anim. Reprod. 8, 4-6.

Welschen, R. \& Dullaart, J. (1974) Serum concentrations of follicle-stimulating hormone and luteinizing hormone after unilateral ovariectomy in the adult rat. J. Endocr. 63, 421-422.

Welschen, R., Dullaart, J. \& de Jong, F.H. (1978) Interrelationships between circulating levels of estradiol-17\%, progesterone, FSH and LH immediately after unilateral ovariectomy in the cyclic rat. Biol. Reprod. 18, 421-427.

Received 17 August 1981 